\title{
EFFECT OF ENVIRONMENT ON THE HIGH TEMPERATURE OXIDATION BEHAVIOR OF 718 AND 718PLUS
}

\author{
K. A. Unocic and B. A. Pint \\ Materials Science and Technology Division \\ Oak Ridge National Laboratory, Oak Ridge, TN 37831-6156
}

Keywords: high temperature oxidation, environment, steam, water vapor, 718Plus

\begin{abstract}
Ni-base alloys 718 and 718Plus are widely used for high temperature components in aircraft and power generation turbines under various environment conditions. Laboratory experimental rigs were used to simulate turbine exhaust (air with $10 \% \mathrm{H}_{2} \mathrm{O}$ ), steam and laboratory air at $550^{\circ}-800^{\circ} \mathrm{C}$ for up to $10,000 \mathrm{~h}$ and compared to oxidation in laboratory air. Because component lifetimes can be much longer than $10,000 \mathrm{~h}$, the experiments at $800^{\circ} \mathrm{C}$ were performed in an attempt to simulate longer exposures at lower temperatures but there are concerns about 718 microstructural stability at this temperature. Oxidation in wet air resulted in net mass losses due to the formation of volatile $\mathrm{CrO}_{2}(\mathrm{OH})_{2}$ but $\mathrm{Cr}$ depletion in the substrate was minimal, even at $800^{\circ} \mathrm{C}$. The rate constants for 718 Plus in air tended to be slightly lower than 718 but otherwise few differences in oxidation behavior were observed. The higher Al content in 718Plus or the finer grain size in these specimens may help to reduce the reaction rate.
\end{abstract}

\section{Introduction}

Alloy 718 is widely used for high temperature components in power generation and aircraft turbines [1-2]. In many applications, the service life is expected to be years, while maintaining a stable structure. In order to increase the performance and maximum operating temperature above $650^{\circ} \mathrm{C}$, alloy 718 Plus was developed for improved thermal stability [3]. Alloy 718Plus includes composition changes including an increase to $9 \%$ Co from $0.3 \%$ (with correspondingly less $\mathrm{Fe}$ ), the addition of $1 \% \mathrm{~W}$ and a higher Al content, Table I. The higher Al content promotes the formation of the $\mathrm{Ll}_{2} \gamma^{\prime}$ phase $\left(\mathrm{Ni}_{3}(\mathrm{Al}, \mathrm{Ti})\right)$, which has higher thermal stability than the $\mathrm{DO}_{22} \gamma^{\prime \prime}$ phase $\left(\mathrm{Ni}_{3} \mathrm{Nb}\right)$ [4-7]. The growth rate of $\gamma^{\prime}$ in 718Plus is much slower than the $\gamma^{\prime \prime}$ phase in 718, which results in a reduction in the associated formation rate of the stable orthorhombic $\delta$ phase $\left(\mathrm{Ni}_{3} \mathrm{Nb}\right)$. The addition of $1 \% \mathrm{~W}$ further increases the high temperature strength.

Like other superalloys with a base composition of $\mathrm{Ni} 20 \% \mathrm{Cr}$, alloy 718 has reasonably good high temperature oxidation resistance [8] and more subtle issues such as environmentally-assisted crack growth have been investigated [2,9-12]. The level of $\mathrm{Cr}$ in 718 and 718Plus typically results in the formation of a dual layer external oxide layer or scale with a base metal outer layer such as $\mathrm{NiCr}_{2} \mathrm{O}_{4}$ and a protective $\mathrm{Cr}$-rich inner one, e.g. $\mathrm{Cr}_{2} \mathrm{O}_{3}$ [13-15]. The long-term oxidation rate is typically controlled by growth and transport through this $\mathrm{Cr}$-rich oxide scale. However, alloy additions that have a higher affinity for $\mathrm{O}$ than $\mathrm{Cr}$, such as $\mathrm{Ti}, \mathrm{Al}$ and $\mathrm{Nb}$, may oxidize internally beneath the scale and increase the rate of degradation, or Si can form a nearly continuous inner layer and reduce the rate of scaling [16]. 
Table I. Alloy chemical compositions (weight $\%$ or ppmw for S) determined by inductively coupled plasma analysis and combustion analysis.

\begin{tabular}{lcccccccccccc} 
Material & $\mathrm{Ni}$ & $\mathrm{Cr}$ & $\mathrm{Mo}$ & $\mathrm{Co}$ & $\mathrm{Fe}$ & $\mathrm{Nb}$ & $\mathrm{Ti}$ & $\mathrm{Al}$ & $\mathrm{Mn}$ & $\mathrm{C}$ & $\mathrm{S}$ & Other \\
\hline 718 & 54.1 & 18.0 & 3.1 & 0.3 & 17.6 & 5.0 & 1.0 & 0.5 & 0.1 & 0.04 & $<10$ & $0.10 \mathrm{Si}$ \\
718 Plus & 52.5 & 17.9 & 2.7 & 8.9 & 9.5 & 5.3 & 0.8 & 1.3 & 0.04 & 0.02 & $<1$ & $1 \mathrm{~W}, 0.06 \mathrm{Si}$ \\
\hline
\end{tabular}

The purpose of this laboratory study was to collect oxidation data for alloys 718 and 718 Plus in several application relevant environments, such as air, steam and simulated exhaust gas, with a goal of comparing their performance and developing a long-term oxidation model. Mass change data in air and steam can be used to generate rate constants, however, in the presence of $\mathrm{O}_{2}$ and $\mathrm{H}_{2} \mathrm{O}$, a volatile $\mathrm{CrO}_{2}(\mathrm{OH})_{2}$ reaction product forms [17-23]. The net mass loss makes quantification of this linear reaction mechanism more difficult especially with the small Cr loses near application temperatures of $650^{\circ}-700^{\circ} \mathrm{C}$. Attempts to accelerate the reaction rates by increasing the temperature to simulate longer service times appears to be a flawed strategy because of the microstructural changes that occur in 718 and 718Plus above the normal service temperature.

\section{Experimental Procedure}

Both wrought 718 and forged 718Plus were tested after a standard heat treatment; for 718Plus that was $2 \mathrm{~h}$ at $968^{\circ} \mathrm{C}$ followed by an oil quench then air cooling after treatments for $8 \mathrm{~h}$ at $788^{\circ} \mathrm{C}$ and $8 \mathrm{~h}$ at $704^{\circ} \mathrm{C}$ [23]. High temperature oxidation studies were performed in laboratory air at $650^{\circ}, 700^{\circ}$ and $800^{\circ} \mathrm{C}$ and, to simulate the combustion environment, in air with 10 vol.\% water vapor (wet air). The laboratory air tests were performed with $500 \mathrm{~h}$ cycles (i.e. the specimens were inserted into a hot furnace for $500 \mathrm{~h}$ and then cooled and weighed after each cycle). Each specimen was held in an alumina crucible to capture any spalled oxide and the exposures were conducted in horizontal resistively heated furnaces with alumina reaction tubes. For wet air testing, similar alumina tube furnaces were used with end caps and the $\mathrm{H}_{2} \mathrm{O}$ was added by atomizing deionized water into the flowing air stream and calibrating the amount of injected water with the air flow rate. In this case, the specimens were placed in alumina boats with faces parallel to the gas flow (velocity of $\sim 1.5 \mathrm{~cm} / \mathrm{s}$ ) and $100 \mathrm{~h}$ cycles were used. Exposures in steam (atomized $\sim 0.065 \mu \mathrm{S} / \mathrm{cm}$ conductivity filtered, deaerated and deionized water) were conducted in $500 \mathrm{~h}$ cycles at 17 bar and $550^{\circ}$ or $800^{\circ} \mathrm{C}$ in a high pressure test rig with an alloy 230 containment tube and the specimens held on a vertical alumina tube using Pt-10Rh wire. Oxidation coupons (1.5 $\mathrm{x}$ $10 \times 19 \mathrm{~mm}$ ) were polished to 600 grit (or better) for these experiments. All samples were ultrasonically cleaned in acetone and methanol prior to oxidation testing. In all cases, specimen mass change was measured after exposure using a Mettler Toledo model XP205 balance $( \pm 0.01$ $\mathrm{mg} / \mathrm{cm}^{2}$ accuracy). After exposure, coupons were examined in plan-view and then Cu-plated, sectioned, and polished for metallographic analysis. Characterization included light microscopy (LM), scanning electron microscopy (SEM) using a Hitachi model S4800, and electron probe microanalysis (EPMA) using a JEOL model 8200 with wavelength dispersive $x$-ray analysis. 


\section{Results and Discussion}

Typical microstructures for 718 and 718 Plus are shown in Figure 1. The grains are larger for the alloy 718 specimen. Figure 2 summarizes the laboratory and wet $\left(10 \% \mathrm{H}_{2} \mathrm{O}\right)$ air mass change data obtained at $650^{\circ}$ and $700^{\circ} \mathrm{C}$. As expected, the laboratory air data for both alloys shows nearly parabolic behavior at $650^{\circ}$ and $700^{\circ} \mathrm{C}$, Figures $2 \mathrm{a}$ and $2 \mathrm{~b}$, respectively. In contrast, mass losses were observed for both alloys in wet air at these temperatures. Figure $2 \mathrm{c}$ summarizes the results after $5,000 \mathrm{~h}$ at both temperatures and environments. A consistently lower mass gain was observed for the 718Plus specimens in laboratory air and this difference could be quantified in the parabolic rate constants calculated [24] based on this mass gain data, Table II. For the more relevant wet air environment, the presence of $\mathrm{O}_{2}$ and $\mathrm{H}_{2} \mathrm{O}$ results in the formation of a volatile oxy-hydroxide [18-20] resulting in a net mass loss at both temperatures. Mass losses for Ni-base alloys exposed to $\mathrm{H}_{2} \mathrm{O}$-containing environments at high temperature have been observed previously [21-23].

Figure 3 shows cross-sections of each of the alloy coupons after 5,000 h exposures (except the 10,000h exposure shown in Figure 3a) and provides direct comparison of the scales formed on 718 and 718Plus in most of the environments shown in Figure 2. Consistent with the low mass changes, the reaction products are relatively thin, with occasional oxide nodules as shown in Figure 3d. Often precipitates rich in $\mathrm{Nb}$ or Ti can cause such nodules to form but based on the relatively low mass changes, these nodules do not continue to grow. The thickest oxide was observed on the 718 specimen exposed to wet air at $700^{\circ} \mathrm{C}$, Figure $3 \mathrm{~g}$. The thicker, presumably Fe-rich oxide, may explain the sharp increase in mass observed around 3,000 $\mathrm{h}$. After the increase, the mass gain continued to drop during the next $\sim 2,000 \mathrm{~h}$ of exposure. The higher Fe content in 718 or the larger grain size compared to the 718 Plus specimens may explain the difference in behavior of these alloys at this condition. A finer alloy grain size increases the flux of $\mathrm{Cr}$ along grain boundaries in the alloy thereby promoting chromia scale formation. The $718 \mathrm{Plus}$ specimen exhibited a thinner reaction product after $5,000 \mathrm{~h}$ in wet air at $700^{\circ} \mathrm{C}$ with less internal oxidation, Figure $3 \mathrm{~h}$. Previously, similar results were shown with and without water vapor after $1,000 \mathrm{~h}$ exposures including increased $\mathrm{Cr}$ depletion with water vapor $[22,23]$. $\mathrm{The} \mathrm{Cr}$
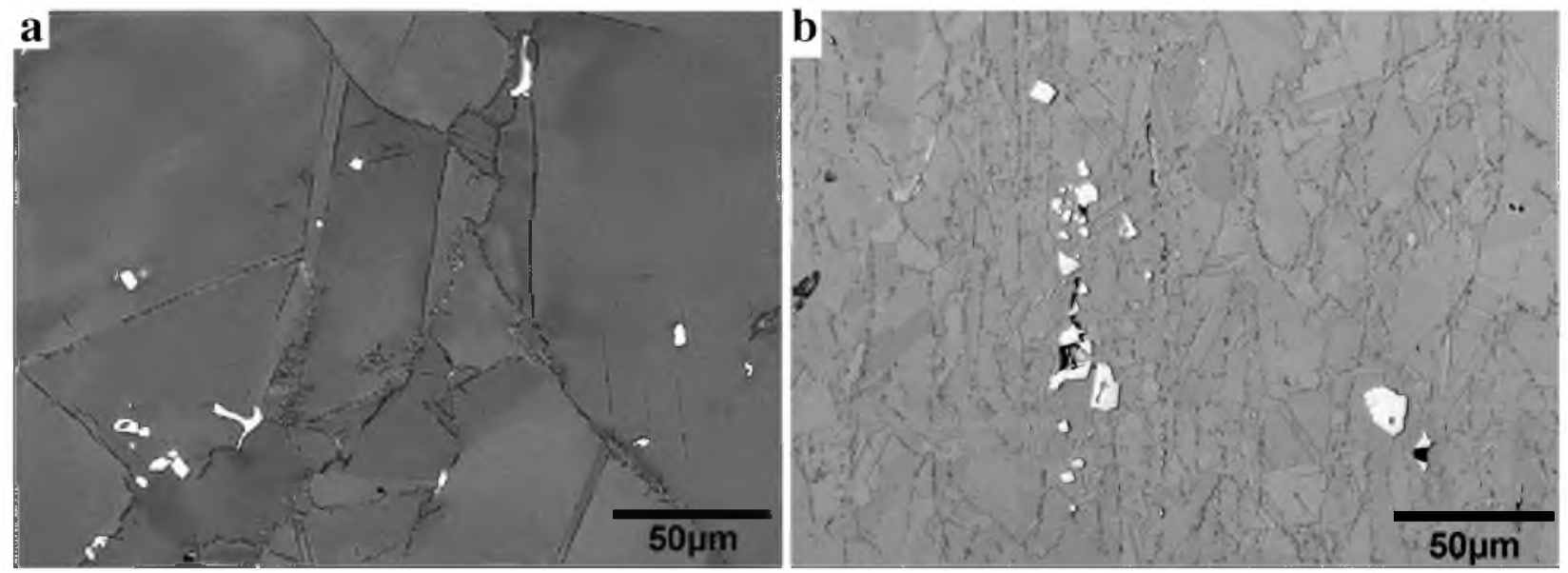

Figure 1. SEM backscattered electron images of the representative microstructure of the wrought alloys (a) 718 and (b) 718Plus. 

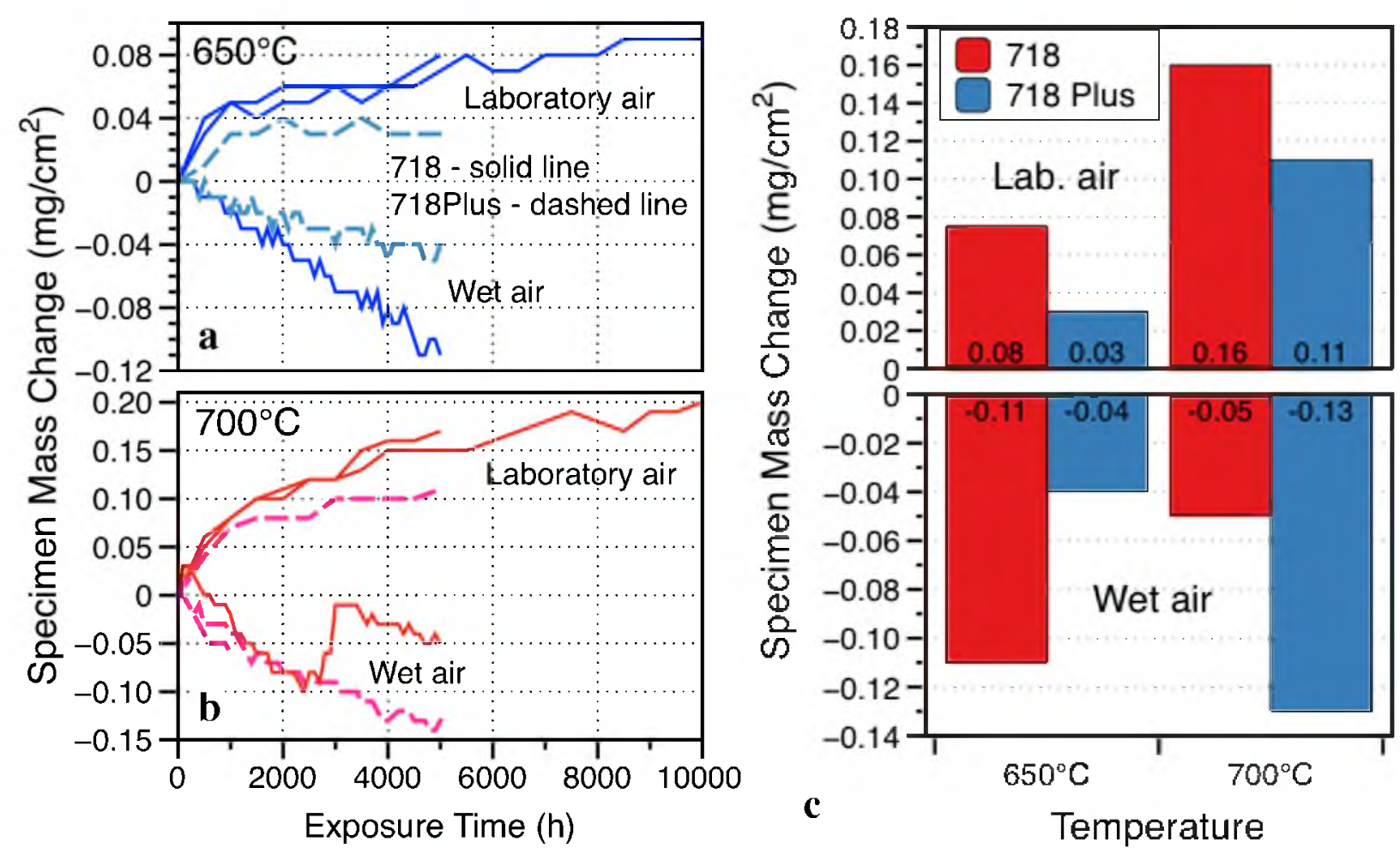

Figure 2. Specimen mass change as a function of exposure time for coupons of alloys 718 (solid lines) and 718Plus (dashed lines) in laboratory air and wet $\left(10\right.$ vol. $\left.\% \mathrm{H}_{2} \mathrm{O}\right)$ air at (a) $650^{\circ} \mathrm{C}$ and (b) $700^{\circ} \mathrm{C}$. (c) summarizes the mass change after $5,000 \mathrm{~h}$ for each condition.

depletion and mass change results are consistent with volatilization and the accelerated $\mathrm{Cr}$ loss in the presence of $\mathrm{O}_{2}$ and $\mathrm{H}_{2} \mathrm{O}$. Figure 4 shows similar EPMA composition profiles for 718Plus after $5,000 \mathrm{~h}$ at $650^{\circ} \mathrm{C}$ in wet air. This is the same cross-section as shown in Figure $3 \mathrm{~d}$. After this longer exposure, no significant $\mathrm{Cr}$ depletion in the substrate was observed at the metal-oxide interface, Also, no depletion was observed in the $\mathrm{Al}$ or $\mathrm{Ti}$ profiles consistent with the limited internal oxidation observed in this specimen. Interdiffusion in the substrate could mask the $\mathrm{Cr}$ loss as $\mathrm{Cr}$ from the center of the specimens diffuses outward to replace $\mathrm{Cr}$ lost due to evaporation. In previous studies, $\mathrm{Cr}$ depletion was more clearly quantified in thin foil specimens where the $\mathrm{Cr}$

Table II. Parabolic rate constant fits from the mass gain data

\begin{tabular}{llcl}
\hline Temperature & Environment & 718 & 718 Plus \\
\hline $550^{\circ} \mathrm{C}$ & steam & $1.5-2.2 \times 10^{-16}$ & \\
$650^{\circ} \mathrm{C}$ & air & $1.4-1.6 \times 10^{-16}$ & $0.2 \times 10^{-16}$ \\
$700^{\circ} \mathrm{C}$ & air & $0.9-1.5 \times 10^{-16}$ & $0.4 \times 10^{-15}$ \\
$800^{\circ} \mathrm{C}$ & air & & $0.8 \times 10^{-14}$ \\
& steam & $1.1-2.9 \times 10^{-14}$ & $0.8-2.3 \times 10^{-14}$ \\
\hline
\end{tabular}




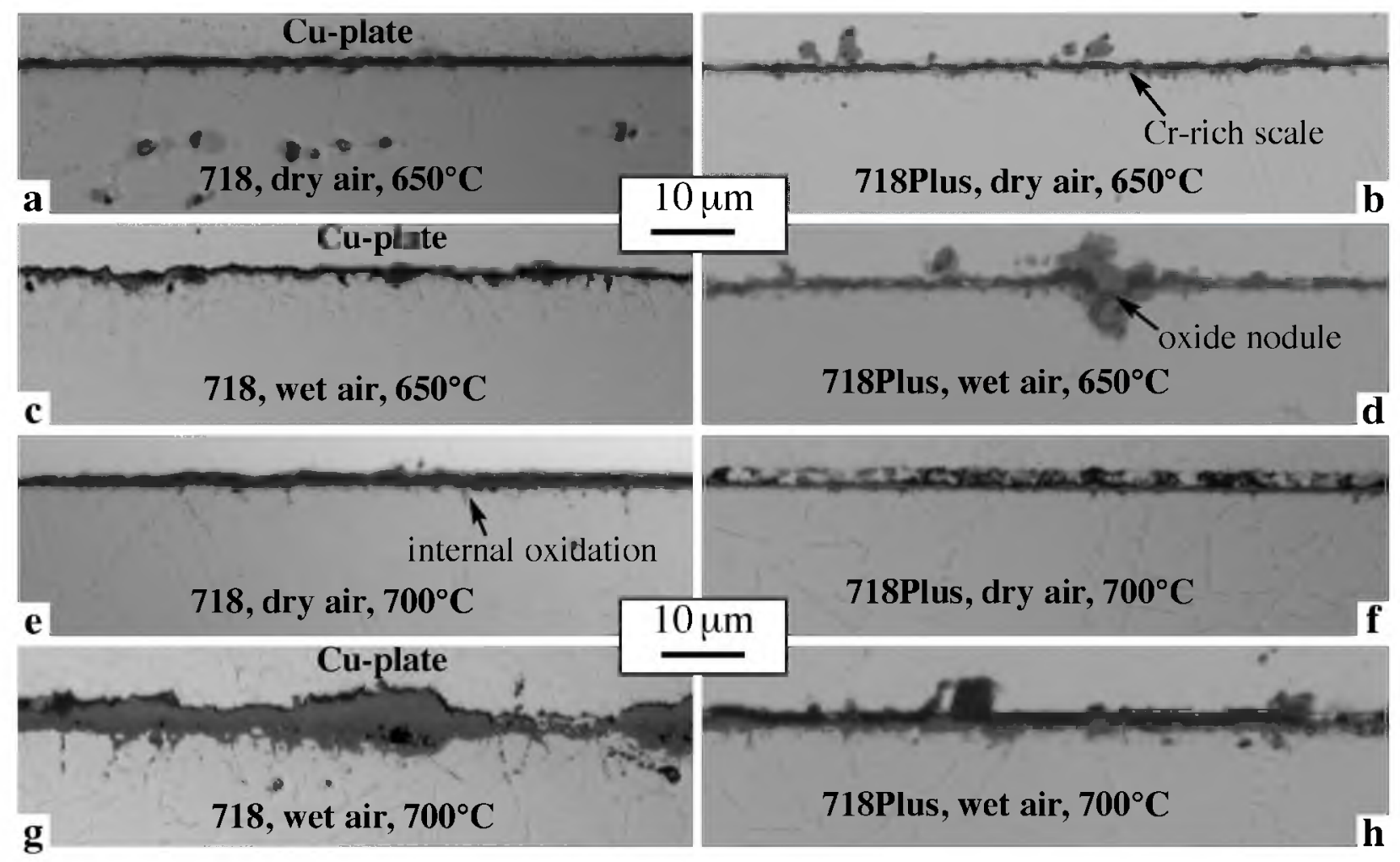

Figure 3. Light microscopy of polished cross-sections of (a) $718,650^{\circ} \mathrm{C}, 10,000 \mathrm{~h}$, dry air, (b) $718 \mathrm{Plus}, 650^{\circ} \mathrm{C}, 5,000 \mathrm{~h}$, dry air, (c) $718,650^{\circ} \mathrm{C}, 5,000 \mathrm{~h}$, wet air, (d) $718 \mathrm{Plus}, 650^{\circ} \mathrm{C}, 5,000 \mathrm{~h}$, wet air, (e) $718,700^{\circ} \mathrm{C}, 5,000 \mathrm{~h}$, dry air, (f) $718 \mathrm{Plus}, 700^{\circ} \mathrm{C}, 5,000 \mathrm{~h}$, dry air, (g) $718,700^{\circ} \mathrm{C}, 5,000 \mathrm{~h}$, wet air and (h) 718 Plus, $700^{\circ} \mathrm{C}, 5,000 \mathrm{~h}$, wet air.

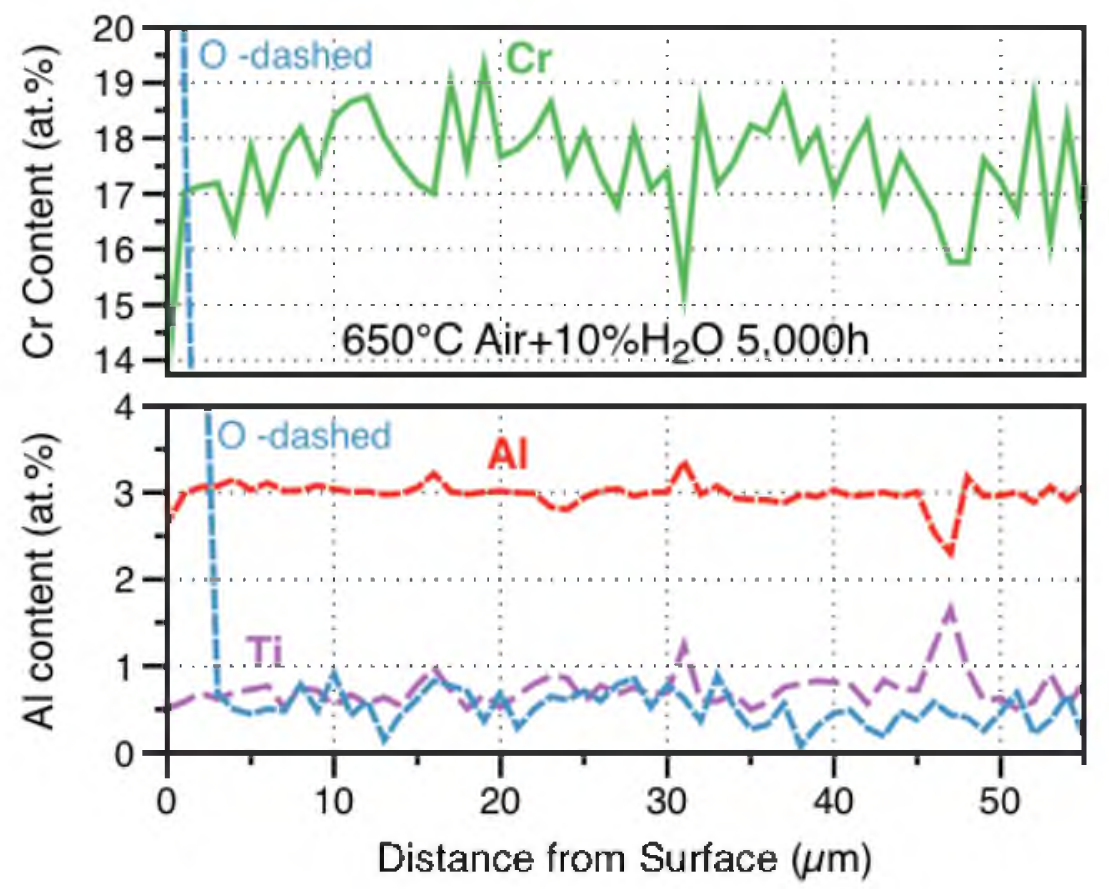

Figure 4. EPMA line profiles of 718 Plus after $5,000 \mathrm{~h}$ at $650^{\circ} \mathrm{C}$ in wet air. 
reservoir was much more limited $[20,21]$.

Figure 5 shows the mass change data obtained at $800^{\circ} \mathrm{C}$. As at the lower temperatures, the mass gain for 718Plus in laboratory air appears to follow parabolic behavior, while a more significant mass loss was observed with the addition of water vapor at this temperature. The mass gains in 17 bar steam were similar as in air, although there was more scatter in the results. Steam testing at $800^{\circ} \mathrm{C}$ was conducted in support of the U.S. Advanced Ultra-Supercritical (A-USC) steam boiler and turbine programs, which has the goal of increasing steam conditions in coal-fired boilers to -350 bar $(5,000 \mathrm{psi})$ and $760^{\circ} \mathrm{C}[25,26]$ from current peak conditions of $250 \mathrm{bar} / 607^{\circ} \mathrm{C}$ [27]. To meet these goals and significantly improve efficiency, Ni-base alloys will be needed in both the boiler tubing and steam turbine. Consistent with the results from other Ni-base alloys tested at this condition [28,29], mass gains similar to those observed in air oxidation were observed in steam. Unlike the wet air environment, little free $\mathrm{O}_{2}$ is available to form $\mathrm{CrO}_{2}(\mathrm{OH})_{2}$ in steam, thus no mass loss was observed,

Figure 6 shows cross-sections from the specimens after 5,000 h at $800^{\circ} \mathrm{C}$. Consistent with the higher mass gains, thicker surface oxides were observed at this temperature than at lower temperatures, Figure 3. Also, more significant internal oxidation was observed at this temperature, especially in wet air, Figure 6b. Specimens of 718 were only exposed in steam at this high temperature so the only direct comparison between the two alloys is shown in Figures $6 \mathrm{c}$ and $6 \mathrm{~d}$. The internal oxidation of $\mathrm{Al}$, Ti and $\mathrm{Nb}$ appeared to be greater for 718 . The crosssections at $800^{\circ} \mathrm{C}$ all showed large $\delta$ precipitates (beneath the reaction front) and the internal attack tended to follow the matrix $\delta$ interface [23]. The microstructure difference with temperature is clearly shown at higher magnification in Figure 7 where the large $\delta$ and $\gamma^{\prime}$ precipitates were seen only after the $800^{\circ} \mathrm{C}$ exposure. The large $\delta$ phase volume shown in Figure

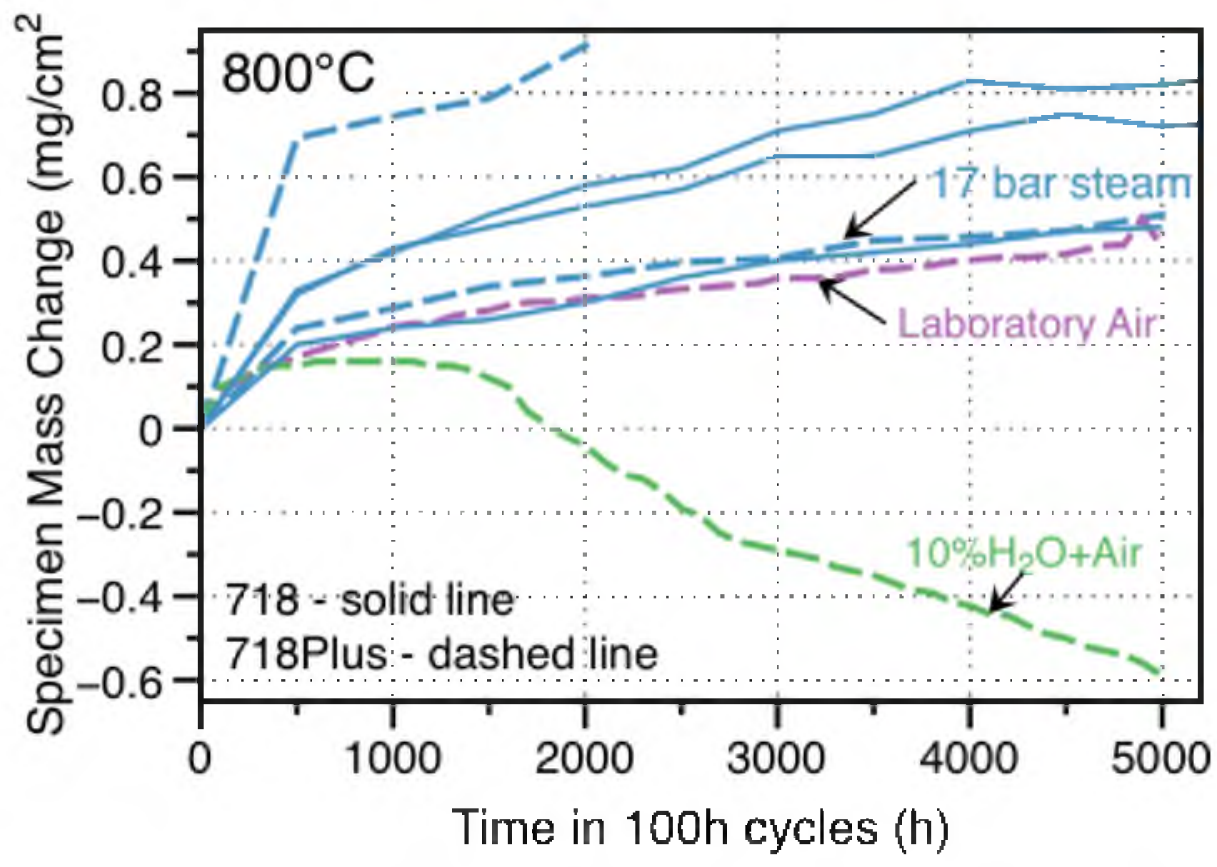

Figure 5. Specimen mass gain of 718 and $718 \mathrm{Plus}$ at $800^{\circ} \mathrm{C}$ in different environments. 


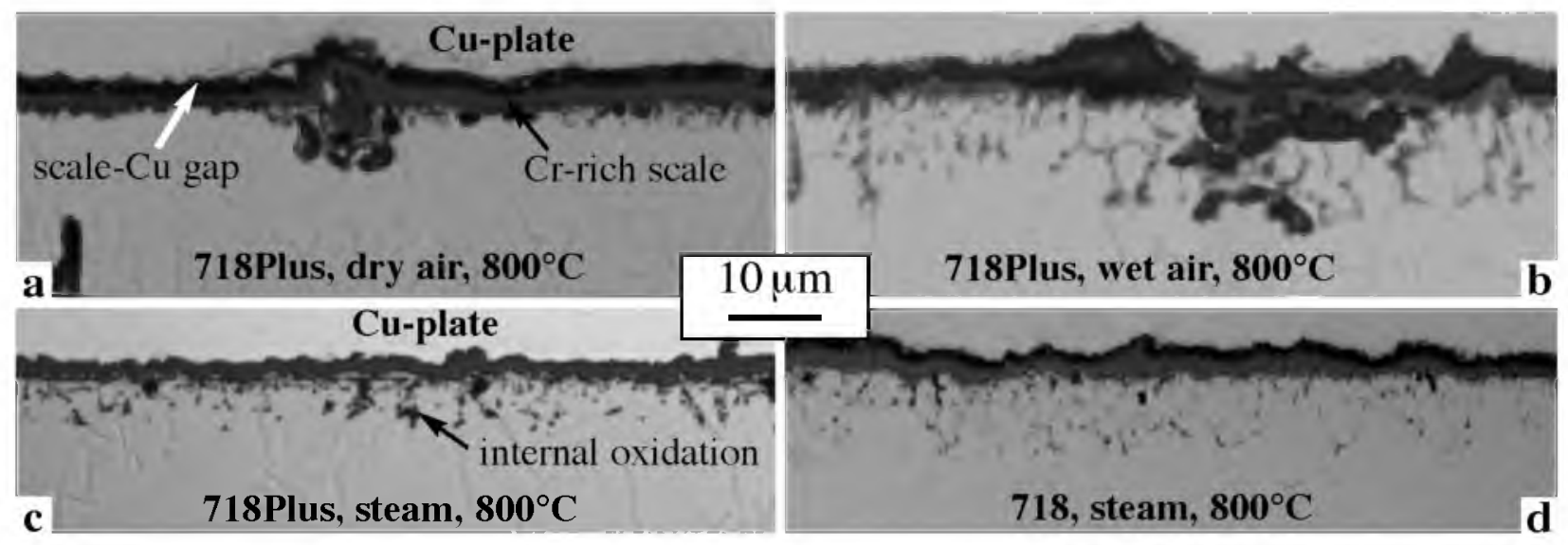

Figure 6. Light microscopy of polished cross-sections of coupons exposed for $5,000 \mathrm{~h}$ at $800^{\circ} \mathrm{C}$, 718Plus in (a) dry air, (b) wet air and 17 bar steam and (d) alloy 718 exposed in 17 bar steam.

$7 \mathrm{~b}$ is attributed to the high temperature exposure, far above any expected application.

Previously, the effect of $\mathrm{Al}$ and $\mathrm{Ti}$ on mass gain in steam was ranked for a variety of cast and wrought Ni-base alloys [29]. Figure 8 shows the ranking of 718 and 718Plus as a function of their $\mathrm{Al}$ and Ti content. Alloys with higher $\mathrm{Al}$ and Ti levels (and correspondingly higher $\gamma^{\prime}$ fractions) showed much higher mass gains in steam oxidation testing at $800^{\circ} \mathrm{C}$. The parabolic rate constants for steam and laboratory air at $800^{\circ} \mathrm{C}$ are also shown in Table II.

Figure 9 compares the composition profiles for the 718Plus specimens exposed in laboratory air and wet air after $5,000 \mathrm{~h}$ at $800^{\circ} \mathrm{C}$ (the same sections shown in Figures $6 \mathrm{a}$ and $6 \mathrm{~b}$, respectively). Unlike after the $650^{\circ} \mathrm{C}$ exposure, Figure 4 , clear $\mathrm{Cr}$ depletion was evident in these specimens and the $\mathrm{Cr}$ loss was significantly greater with the addition of water vapor due to the additional loss by evaporation. However, the depletion depth is still only $20 \mu \mathrm{m}$ after $5,000 \mathrm{~h}$. The Al profiles are also shown in Figure 9. The high values observed for the specimen exposed in wet air are

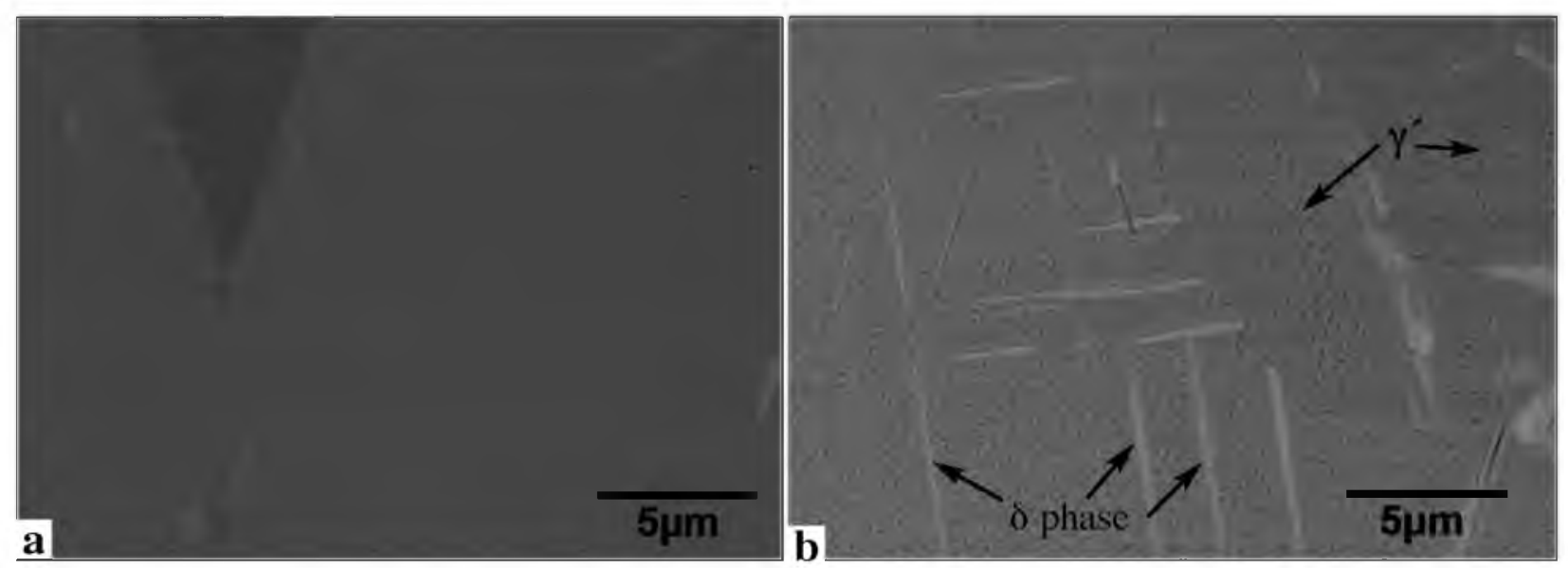

Figure 7. SEM backscattered electron image of 718Plus after 5,000h exposures in wet air at (a) $650^{\circ} \mathrm{C}$ and (b) $800^{\circ} \mathrm{C}$. 


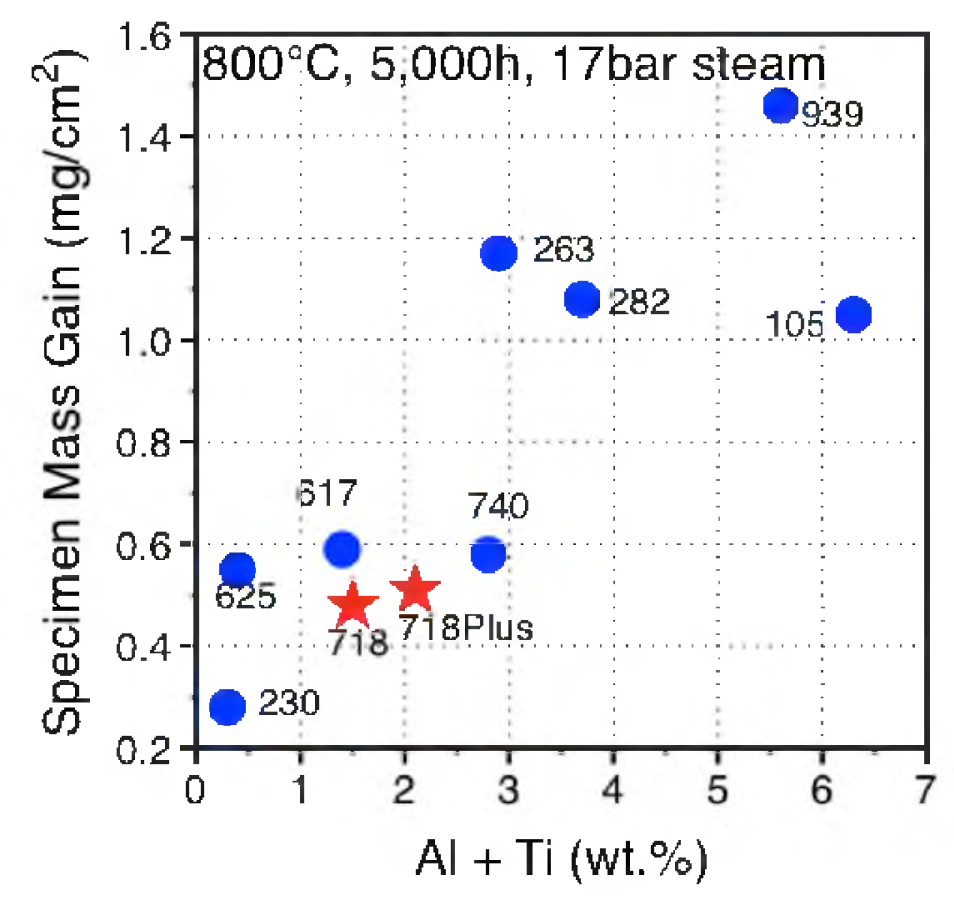

Figure 8. Specimen mass gain from Figure 5 after $5,000 \mathrm{~h}$ at $800^{\circ} \mathrm{C}$ in $17 \mathrm{bar}$ steam plotted as a function of the alloy $\mathrm{Al}+\mathrm{Ti}$ content and compared to other wrought superalloys.

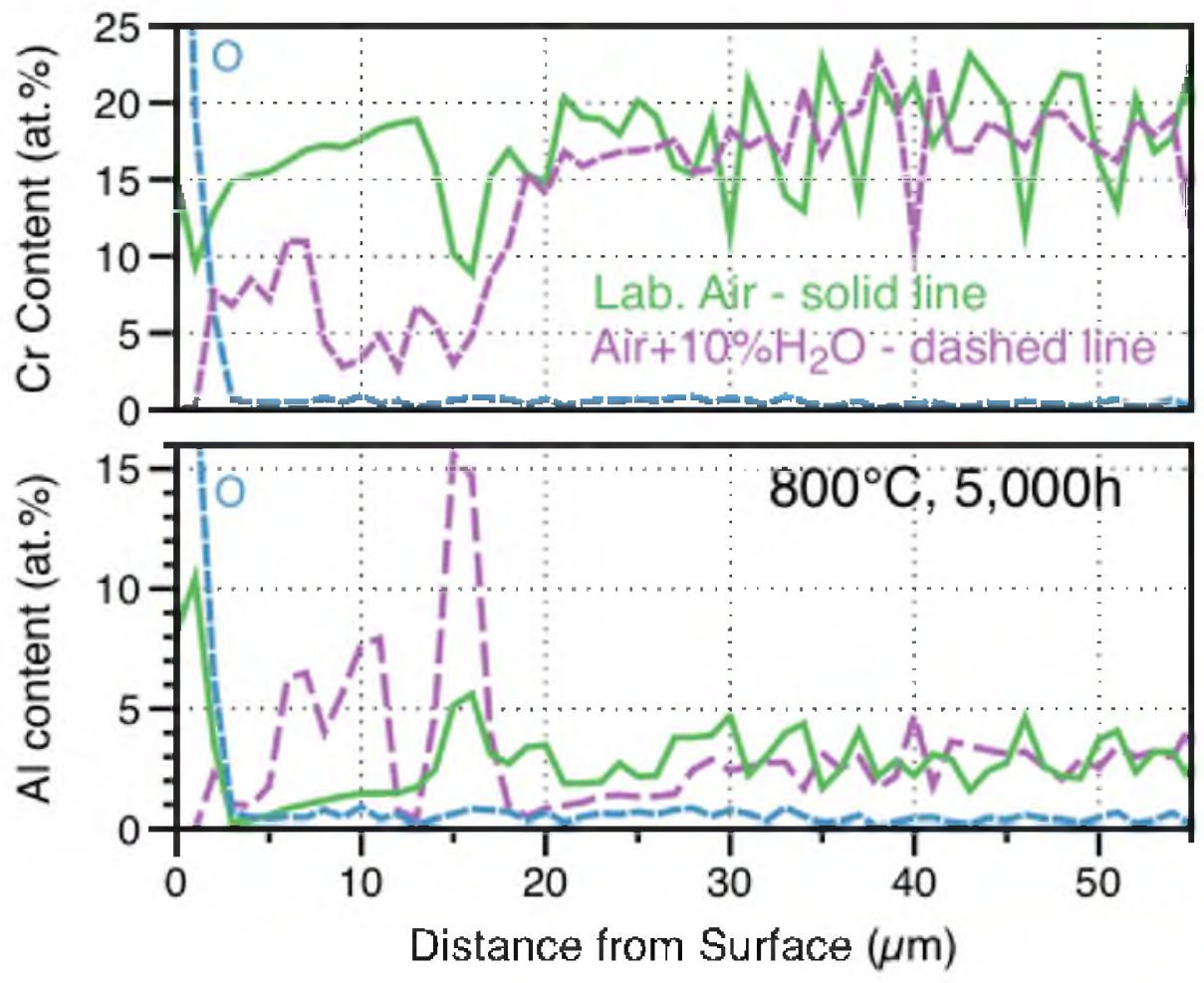

Figure 9. EPMA line profiles of 718 Plus after $5,000 \mathrm{~h}$ at $800^{\circ} \mathrm{C}$ in laboratory and wet air. 
consistent with the internal oxidation observed in Figure 6b. Interestingly, a large Al peak was observed in the scale grown in laboratory air. This may suggest a beneficial effect of the higher $\mathrm{Al}$ content in 718Plus (whereby transport may be slower through a scale with a higher $\mathrm{Al}$ content) and explain the lower oxidation rates observed at lower temperatures in laboratory air. A beneficial effect of $\mathrm{Al}$ also may occur in wet air, where the mass loss was less for 718Plus at $650^{\circ} \mathrm{C}$, Figure $2 \mathrm{a}$, and a thinner oxide forms at $700^{\circ} \mathrm{C}$, compare Figures $3 \mathrm{~g}$ and $3 \mathrm{~h}$. As mentioned previously, the finer 718 Plus grain size in this study may also have affected the behavior.

Figure 10 is an Arrhenius plot of the rate constants in Table II. Also included in Figure 10 and Table II are rate constants for 718 specimens exposed in 17 bar steam at $550^{\circ} \mathrm{C}$. In laboratory air, the rate constants for 718Plus are lower. Separate activation energies were calculated for 718 and 718 Plus in laboratory air and shown in Figure 10. These values of 327 and $304 \mathrm{~kJ} / \mathrm{mol}$ are higher than those reported for cycled alloy $718(177 \mathrm{~kJ} / \mathrm{mol}$ ) [30] and model $\mathrm{NiCr}$ and $\mathrm{FeCr}$ alloys (250 $\mathrm{kJ} / \mathrm{mol}$ ) [31,32] but consistent with a commercial $\mathrm{NiCr}$ alloy $300 \mathrm{~kJ} / \mathrm{mol}$ [32], although these studies all covered higher temperature ranges $\left(750^{\circ}-1200^{\circ} \mathrm{C}\right)$ than were studied here. For oxidation in 17 bar steam, only two temperatures are shown in Figure 10 for 718 (connected by a dotted line). More data are needed to understand the effect of temperature on the rate constant in steam.

\section{Summary}

Long-term $(5,000-10,000 \mathrm{~h})$ oxidation exposures were conducted to compare the oxidation behavior of alloys 718 and 718Plus. A lower oxidation rate was observed for 718 Plus in laboratory air at $650^{\circ}-700^{\circ} \mathrm{C}$. Alloy 718 Plus also appeared to be more protective in wet air. Both

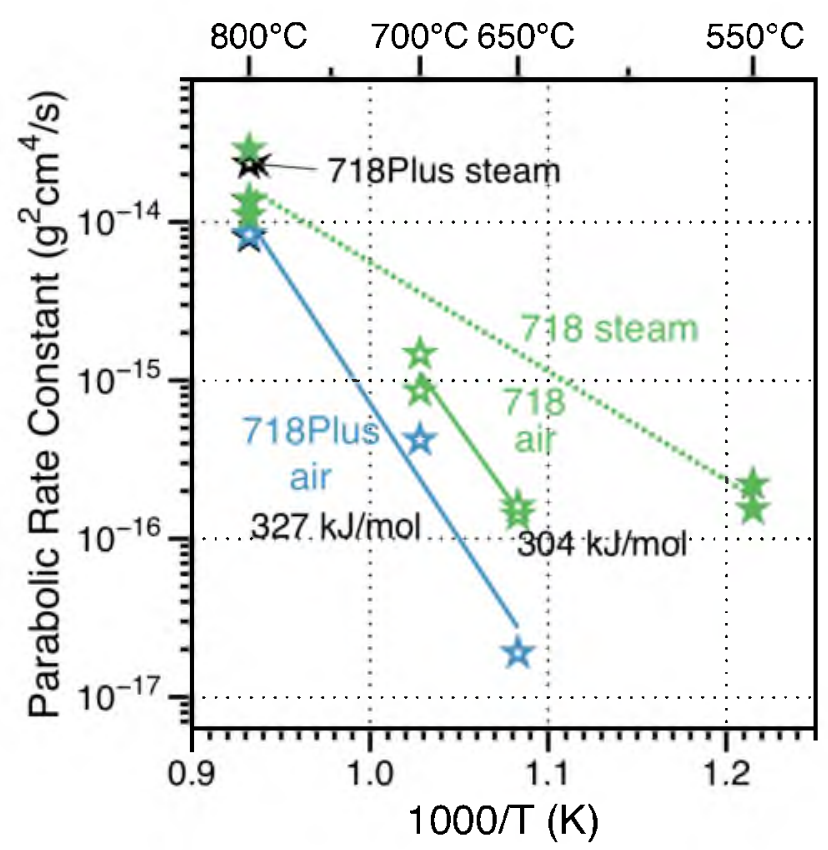

Figure 10. Arrhenius plot of 718 and 718Plus rate constants in Table 2 with fits of the air data for each alloy. 
observations may be related to the finer grain size of the material studied here or a beneficial effect of the higher $\mathrm{Al}$ content in 718Plus compared to 718. Oxidation experiments also were conducted at $800^{\circ} \mathrm{C}$ to accelerate the reaction to simulate longer time exposures at lower temperatures. However, microstructural changes in 718 and 718Plus at this temperature make this strategy questionable.

\section{Acknowledgments}

The authors would like to thank P. F. Tortorelli at ORNL for comments on the manuscript. At ORNL, D. Leonard, G. Garner, T. Lowe, M. Stephens, M. Howell, H. Longmire and T. Jordan assisted with the experimental work. This paper was assembled with support from the U.S. Department of Energy, Office of Coal and Power R\&D, Office of Fossil Energy, (R. Dennis program manager).

\section{References}

[1] J. F. Radavich, "Long Time Stability of a Wrought Alloy 718 disk," Superalloy 718 Metallurgy and Applications (1989), 257-268.

[2] D.A. Woodford, "Gas Phase Embrittlement and Time Dependent Cracking of Nickel Based Superalloys," Energy Materials, 1 (2006), 59-79.

[3] R. L. Kennedy, "Allvac (R) 718PlusTM, Superalloy for the Next Forty Years," 6th International Symposium on Superalloy 718, 625, 706 and Derivatives, ed. E. A. Loria (Warrendale, PA: TMS, 2005), 1-14.

[4] M. Sundararaman, P. Mukhopadhyay and S. Banerjee, "Precipitation of the $\delta-\mathrm{Ni}_{3} \mathrm{Nb}$ Phase in Two Nickel-Base Superalloys," Metallurgical Transactions A, 19A (1988), 453-465.

[5] M. Sundararaman, P. Mukhopadhyay, S. Banerjee, "Some Aspects of the Precipitation of Metastable Intermetallic Phases in Inconel 718," Metallurgical Trans. A, 23A (1992), 2015-2028.

[6] J. P. Collier, S. H. Wong, J. C. Phillips and J. K. Tien, "The Effect of Varying A1, Ti, and Nb Content on the Phase Stability of Inconel 718," Metallurgical Trans. A, 19A (1988), 16571666.

[7] J. P. Collier, A. O. Selius and J. K. Tien, "On Developing a Microstructurally and Thermally Stable Iron-Nickel Base Superalloy," Superalloys 1988, ed. M. Gell, et al. (Warrendale, PA: TMS, 1988), 43-52.

[8] L. Geng, Y.S. Na and N. K. Park, "Oxidation behavior of alloy 718 at high temperature," Materials and Design, 28 (2007), 978-981.

[9] R. Molins, G. Hochstetter, J. C. Chassaigne and E. Andrieu, "Oxidation Effects on the Fatigue Crack Growth Behavior of Alloy 718 at High Temp.," Acta Mater., 45 (1997), 663-674.

[10] D. A. Woodford, "Environmental Damage of a Cast Nickel-Base Superalloy," Met. Trans., 12 (1981), 299-308.

[11] U. Krupp, "Dynamic embrittlement - time-dependent quasi-brittle intergranular fracture at high temperatures," Inter. Mater. Rev., 50 (2005), 83-97.

[12] A. Pineau and S. D. Antolovich, "High temperature fatigue of nickel-base superalloys - A review with special emphasis on deformation modes and oxidation," Eng. Failure Analysis, 16 (2009), 2668-2697.

[13] G. C. Wood, T. Hodgkiess and D. P. Whittle, "A Comparison of the Scaling Behaviour of Pure Iron-Chromium and Nickel-Chromium Alloys in Oxygen," Corr. Sci., 6 (1966), 129-147. 
[14] H. M. Hindam and D. P. Whittle, "Microstructure, Adhesion and Growth Kinetics of Protective Scales on Metals and Alloys," Oxid. Met., 18 (1982), 245-284.

[15] B. Jönsson and C. Svedberg, "Limiting Factors for Fe-Cr-Al and $\mathrm{NiCr}$ in Controlled Industrial Atmospheres," Mat. Sci. Forum, 251-254 (1997), 551-558.

[16] D. L. Douglass, "A Critique of Internal Oxidation in Alloys During the Post-Wagner Era," Oxid. Met., 44 (1995), 81-111.

[17] G. C. Wood, I. G. Wright, T. Hodgkiess, D. P. Whittle, "A Comparison of the Oxidation of Fe-Cr, Ni-Cr and Co-Cr Alloys in Oxygen and Water Vapor," Werk. Korr., 21 (1970), 900-910.

[18] H. Asteman, J.-E. Svensson, M. Norell and L.-G. Johansson, "Influence of Water Vapor and Flow Rate on the High-Temperature Oxidation of 304L; Effect of Chromium Oxide Hydroxide Evaporation," Oxid. Met., 54 (2000), 11-26.

[19] E. J. Opila, "Volatility of Common Protective Oxides in High-Temperature Water Vapor: Current Understanding and Unanswered Questions," Mater. Sci. Forum, 461-464 (2004), 765-74.

[20] D. J. Young and B. A. Pint, "Chromium Volatilization Rates from $\mathrm{Cr}_{2} \mathrm{O}_{3}$ Scales Into Flowing Gases Containing Water Vapor," Oxid. Met., 66 (2006), 137-153.

[21] B. A. Pint, "The Effect of Water Vapor on Cr Depletion in Advanced Recuperator Alloys," (ASME Paper \#GT2005-68495, presented at the International Gas Turbine \& Aeroengine Congress \& Exhibition, Reno-Tahoe, NV, June 6-9, 2005).

[22] B. A. Pint, K. A. Unocic and S. Dryepondt, "Oxidation of Superalloys in Extreme Environments," 7th International Symposium on Superalloy 718 and Derivatives, ed. E. Ott, et al. (Warrendale, PA: TMS, 2010), 861-875.

[23] K. A. Unocic, R. R. Unocic, B. A. Pint and R. W. Hayes, "Effect of Microstructure and Environment on the High-Temperature Oxidation Behavior of Alloy 718Plus," 7th International Symposium on Superalloy 718 and Derivatives, ed. E. Ott, et al. (Warrendale, PA: TMS, 2010), 977-991.

[24] B. Pieraggi, "Calculations of Parabolic Reaction Rate Constants," Oxid. Met., 27 (1987), $177-85$.

[25] R. Viswanathan, J.F. Henry, J. Tanzosh, G. Stanko, J. Shingledecker, B. Vitalis, and R. Purgert, "U.S. Program on Materials Technology for Ultra-Supercritical Coal Power Plants," J. Mater. Eng. Performance 14(3) (2005) 281-285.

[26] R. Viswanathan, J. Shingledecker and R. Purgert, "Evaluating Materials Technology for Advanced Ultrasupercritical Coal-Fired Plants," Power, 154(8) (2010), 41-45.

[27] B. A. Pint, "High-Temperature Corrosion in Fossil Fuel Power Generation: Present and Future," JOM, 65 (2013), 1024-1032.

[28] I. G. Wright and R. B. Dooley, "A review of the oxidation behavior of structural alloys in steam," Inter. Mater. Rev., 55 (3) (2010), 129-167.

[29] E. Essuman, L. R. Walker, P. J. Maziasz and B. A. Pint, "Oxidation Behavior of Cast NiCr Alloys in Steam at 800C," Materials Science and Technology, 29 (2013), 822-827.

[30] Kh. A. Al-hatab, M. A. Al-bukhaiti, U. Krupp and M. Kantehm, "Cyclic Oxidation Behavior of IN 718 Superalloy in Air at High Temperatures," Oxid. Met., 75 (2011), 209-228.

[31] F. Toscan, L. Antoni, Y. Wouters, M. Dupeux and A. Galerie, "Oxidation Kinetics and Scale Spallation of Iron-Chromium Alloys with Different Titanium Contents," Mater. Sci. Forum, 461-464 (2004), 705-712.

[32] G. Ben Abderrazik, G. Moulin and A. M. Huntz, "Relation Between Impurities and OxideScale Growth Mechanisms on Ni-34Cr and Ni-20Cr Alloys. I.Influence of C, Mn, and Si," Oxid. Met., 33 (1990), 191-235. 